\title{
Forage Plants of Chechnya and Classification of Natural Forage Lands
}

\author{
Taysumov M.A. \\ Department of Biological Studies \\ Kh. Ibragimov Complex Institute of the \\ Russian Academy of Science \\ Grozny, Russia \\ musa_taisumov@mail.ru \\ Umarov R.M. \\ Department of Biological Studies \\ Academy of Sciences of the Chechen Republic \\ Grozny, Russia \\ umarovbiolog@mail.ru
}

Magomadova R.S.

Faculty of Natural Science

Chechen State Pedagogical Institute

Grozny, Russia

r.s.magomadova@mail.ru

Khanaeva Kh.R

Faculty of Natural Science

Chechen State Pedagogical Institute

Grozny, Russia

xeda.xanaeva@bk.ru

\begin{abstract}
This paper reviews the results of botanical studies of the plant cover of natural forage lands of Chechnya and adjacent territories with the goal of developing recommendations for their sustainable use and protection. The study reveals the typological structure and territorial distribution of acreages; the current state and features of the species usage are estimated; the floristic and biomorphic diversity of the plant cover is researched.

The object of the research is the flora of forage plants of the Chechen Republic and adjacent territories. The studies were carried out with the help of the traditional route approach; the most interesting areas were studied in detail and their floristic lists were created. The main way of logging the information was herbarium collections. Besides, the data obtained when working with the herbarium collections at the herbarium repositories of the Chechen State Pedagogical University, the Complex Scientific Research Institute of RAS, Academy of Sciences of the Chechen Republic were used. When compiling the systematic list, the data published in "Flora of the USSR", "Flora of the Caucasus", "Flora of the North Caucasus", "Notes about the Flora of the Chechen Republic", as well as some monographs on individual taxa are taken into account. In the course of the expeditionary research, in addition to the herbarium collections, various
\end{abstract}

\author{
Astamirova M.A.-M. \\ Faculty of Natural Science \\ Chechen State Pedagogical Institute \\ Grozny, Russia \\ astamirova@bk.ru
}

\author{
Abdurzakova A.S. \\ Faculty of Natural Science \\ Chechen State Pedagogical Institute \\ Grozny, Russia \\ anna-grozny@mail.ru
}

Israilova S.A.

Faculty of Natural Science

Chechen State Pedagogical Institute

Grozny, Russia

s.israilova@yandex.ru

\author{
Khasueva B.A. \\ Faculty of Natural Science \\ Chechen State Pedagogical Institute \\ Grozny, Russia \\ khasueva_013@mail.ru
}

observations were made concerning phenology, habitat types, phytocenotic role, and ecological attribution of the species.

The research results. The state of mountain meadows and their species structure are researched. The fodder qualities of various species of gramineuos plants, sedges, legumes and wild grasses recommended for improving natural meadows and pastures are indicated. The types of the defined groups having different economic value (well eaten, nutritious, of the secondary importance, poisonous, weedy) are listed. The principles of the species selection for the goals of enrichment and qualitative improvement of mountain meadows are defined; they refer to their feeding advantages, fresh yield, resistance to trampling, regenerative ability, high competitiveness and other bioecological features adequate to the conditions of the improved coenosis. For the meadows and pastures of different altitudes, orientations of slopes and various substrates a large set of species promising for a qualitative improvement of mountain pastures is proposed. The research results are of practical value and can be taken into account in the economic usage of mountain meadows and pastures of the North Caucasus.

Keywords-Chechnya, botanical studies, forage species, plant cover, plant communities, floral diversity 


\section{INTRODUCTION}

The study of plant resources for the purpose of their rational use and protection is one of the main tasks of modern biology and medicine. The development of resource sectors in various areas of industry involves the expansion of the list of the useful species taking into account the experience of their usage in feed production and in agricultural practice. The search for new forage and edible plants requires a comprehensive study of flora and vegetation, as well as carrying out the integrated ecological and biological research based on synthesis, refinement and expansion of theoretical, methodological and practical recommendations. The population-based studies can be considered as one of the priorities. The identification of the population attribution of species to the existing ecological and coenotic conditions, the specification of the demographic parameters, the study of the development dynamics, the methods of self-maintenance, the survival strategies of species and populations provide the basis for the sustainable usage of plant resources.

Currently, in the developed countries of America, Europe and Asia about $80 \%$ of the population prefer natural forage. This trend is also observed in Russia. On the territory of Chechnya there are more than a hundred species that can be regarded as valuable feed plants.

First of all, the reduction of biological resources is associated with the irrational procurement of forage raw materials by various procurement organizations and private persons who do not pay enough attention to the rules of collecting technology and the requirements of supportive actions. Ecological and biological research, methodological and practical recommendations developed on the basis of experimental data will allow preserving and enriching the biodiversity of plant resources.

\section{Methods AND MATERIALS}

The object of the research is the flora of forage plants of the Chechen Republic and adjacent territories. The studies were carried out with the help of the traditional route approach; the most interesting areas were studied in detail and their floristic lists were created. The main way of logging the information was herbarium collections. Besides, the data obtained when working with the herbarium collections at the herbarium repositories of the Chechen State Pedagogical University, the Complex Scientific Research Institute of RAS, Academy of Sciences of the Chechen Republic were used. When compiling the systematic list, the data published in "Flora of the USSR", "Flora of the Caucasus", "Flora of the North Caucasus", "Notes about the Flora of the Chechen Republic", as well as some monographs on individual taxa are taken into account. In the course of the expeditionary research, in addition to the herbarium collections, various observations were made concerning phenology, habitat types, phytocenotic role, and ecological attribution of the species.

\section{RESULTS}

On the territory of the Chechen Republic there are about 2318 plant species; among them there are species that have valuable forage qualities and ill weeds [1-3].

Unfortunately, the majority of pastures are unproductive lands, as there are up to $70-80 \%$ of ballast and harmful species in their herbage. For example, all variegated fescue grass fields, clusters with Nardus stricta L., wastelands, empty meadows, marshy meadows, etc. are unproductive. To improve these lands, first of all, it is necessary to improve the species composition of the plant cover, as the fodder value of the herbage is estimated namely on the basis of the species. Within this context one should begin the improvement of pastures with studying the floral list of meadows, determining the share of species in specific groups, estimating the forage value (nutrient content, key representatives), etc. It is well known that various species, even allied ones, have different value. It is not enough to know, for example, that this species is fescue, clover or sainfoin, the main thing is to know the subtype of the given fescue, clover and sainfoin. Meadow fescue is an excellent fodder grass; variegated fescue is a harmful weed. The types of clover and sainfoin are also qualitatively different. The populations are unequal as well; for example, Trifolium ambigum Bieb. - in the area of the Terek ridge it has 3\% less protein than in the area of the Kezenoyam.

The studies of the forage values of the North Caucasian species began long ago, but the results are, unfortunately, very poor. There are only preliminary data, but they allow starting the improvement of mountain pastures from the scientific point of view. The first conclusion that can be derived from the analysis of the floral composition of the natural forage lands in Chechnya is that there are still many valuable forage plants in the meadows, though they grow in spots or even very sparsely. Good pastures should have the prevailing number of valuable species, maybe even the dominating one. To achieve this goal various measures should be taken; some of them were mentioned in one of the authors' works devoted to the genepool of the flora of Chechnya [4]. Among them there is direct control of weeds and poisonous herbs, destruction of hillocks, drainage of marshy lands and wetlands, application of fertilizers stimulating the development and the depression of the definite species, organization of herding pastures and planting herbs that influence the change in the herbage botanical composition directly or indirectly, etc. So what kinds of the mountain flora of Chechnya in view of their nutritional value and palatability can be considered as the most valuable? 
Regarding the Poaceae Barnhart family, the following species can be noted: Agrostis planifolia (C. Koch) Tzvel. (8,2\%-14\% of protein*) $)^{1}$, Alopecurulus sericeus Alb. (17-19\% of protein), A. pratensis $L$. and A. venticosus Pers. (11-12\%), Arrhenantherum elatius (L.) J. Presl \& C. Presl (up to $11 \%$ ), Dactylis glomerata L. (up to $10 \% *$ ), Deschampsia caespitosa (L.) P. Beauv. (11\%*), Festuca rubra L. (14-15\%), F. pratensis Huds. $(13 \% *), F$. valesiaca Gaudin $(10 \%)$, Hordeum violaceum Boiss. \& A. Huet (11-12-49\%*) - the latter species is high-yielding and gives tender hay; Koeleria gracilis Pers. (8-15\%*), K. caucasica (Domin) B. Fedtsch. as well as K. buschiana Gontsch., Lolium perenne L. (excellent pasture grasses containing about $10 \%$ of protein); Phleum alpinum $L$. (10-11\%*), Ph. nodosum L. (10-12\%), Ph. pratense L. (810\%*), Ph. montanum C.Koch (10\%); Poa iberica Fisch. et C.A. Mey., P. meyeri Trin. ex Roshev., P. pratensis L. (all of them contain about 8-12\%), Poa alpina L. (12.9\%), P. nemoralis $L$. $(11.54 \% *)$, P. trivialis $L$. $(10,7 \% *)$; Zerna inermis Leyss. (8-11\%), Z. riparia (Rehm.) Nevski (11.7\%), Z. variegate (Bieb.) Nevski (8-10\%*), Z. bibersteinii (Roem. Et Schult.) Nevski (about 10\%*).

The following species are also of value: Helictotrichon Bess., Agropyron Gaertn. (7-10\%), species of the genera Briza L., Calamagrostis $\left(9-14 \% \%^{*}\right)$ are characterized by good palatability, Alopecurus vaginatus (Wild.) Pall. ex Kunth, Sesleria phleoides Stev. ex Roem.et Schult., species of Stipa L. are well eaten before flowering, etc.

In the beginning of summer the following species of sedges are eaten well - Carex obtusata Lilebl., C. vulpine L., C. meinshauseniana V. Krecz. (7-8\%), C. tristis Bieb. (1012\%); C. humilis Leyss., C. huetiana Boiss., C. verna Shaix, $C$. supina Willd. are eaten not bad, they are eaten mainly before flourishing as the previous species. The rest of the edible species Kobresia cappilifolia (Decne) Clarke and $K$. schoenoides (C.A. Mey.) Steud. is widely spread in the alpine region throughout the North Caucasus. A special role in the meadows is played by Carex tristis Bieb. (in the subalpine and alpine belts) and $C$. humilis Leyss. (in the lower and middle mountain zones).

The following bean species have high fodder value and are eaten well: Anthyllus polyphyllus Wend. (16\%), A. boissierii Juz., Hedysarum caucasicum Bieb., Lathyrus pratensis L., Lotus caucasicus Rupr. ex Jux., Astragalus glycyphyllos L., A. onobrychis $L$. (in the first half of summer), Coronilla balansae (Boiss.) Gross., all the species of the genus Medicago L., especially, M. sativa L. (16\%), M. glutinosa Vass. (excellent forage plant), M. falcata $L$. (12,5-19,3\%), M. lupulina $L$. (up to $22 \%$ ). Such species as Onobrychis bibersteinii Sirj. $\left(19,41 \%{ }^{*}\right)$, O. inermis Steven, O. cyri Grossh., O. petraea (M.

1. All the data refer to the Caucasus. They are partially taken from the works [5] and [6]. Some data are taken from "Manual for the Identification of the Plants of Hayfields and Pastures of the North Caucasus", the rest data marked with an asterisk (*) are taken from unpublished materials of the expedition to the Caucasus [7].
Bieb. ex Willd.) Fisch. (16,76\%*), O. ruprechtii Grossh. (up to 15-16\%), Orobus cyaneus Stev. (20-22\%), Trifolium polyphyllum C.A. Mey., T. spadiceum L., T. elisabethae Klok. (16-20\%), T. hybridum L. (12,73-17,2\%*), T. alpestre L., T. medium L., T. pratense L. (14\%*), T. fontanum Bobrov (1416\%), Vicia dasycarpa Ten. (16,2\%*), V. grossheimii Ekvtim., $V$. balansae Boiss., V. truncatula Fisch. ex M. Bieb. (about $18 \%$ ), V. sepium L. (up to $24 \%$ ), V. grandiflora Scop. (up to $19 \%$ ), V. angustifolia L. (up to $25 \%$ ), V. caucasica Ekvtim., (up to $20 \%$ ) have good characteristics as well. The following species are eaten satisfactorily: Trifolium montanum $L$., $T$. trichocephalumBieb., T. caucasicum Taush., T. canescens Willd., T. arvenseL., Lotus tenuis Waldst. \& Kit. ex Willd., Glycyrriza glabra L., Caronilla varia L. (16\%*), Vicia alpestris Steven., Lathyrus miniatus M. Bieb. ex Steven, L. Tuberosus L., Galega orientalis Lam. - very productive species $(16,4 \%$ of protein in dry matter*), Astragalus galegiformis $L$. (13\%) is eaten not so well. The types of genera Medicago L., Onobrychis Mill. and Trifolium L. are of the greatest interest.

Wild grasses are also classified into the following types: having great forage value, well eaten, nutritious and having secondary importance. The first type is presented by: the buckwheat family - Polygonum viviparum L. (is eaten especially well by sheep) and Polygonum alpestre C.F. Vey. especially before flourishing (Bogdanov,1932); the pink family Arenaria lychnideae Bieb. (is eaten by sheep); the rose family - Filipendula vulgaris Moench ( $F$. hexapetala Gilib.) (13\%), F. ulmaria (L.) Maxim. (11,9\%)*, Sanguisorba officinalis L. (about 10\%), the species of the genera Poterium polygamum Waldst et Kit.; the species of the genus Polygonum L. (especially for sheep); the parsley family Chaerophyllum caucasicum L. $(15,5 \%)^{*}$, Carum carvi L. (up to $24 \%$ ), C. caucasica L. (up to $16 \%$ ), C. meifolium (M. Bieb.) Boiss. (up to $17 \%$ ), Pimpinella saxifrage L. (up to $11 \%$ ), $P$. rodantha. The ensilage species of the genus Heracleum $L$. are also promising, for example, $H$. sibiricum $L$. In view of the borage family only Symphitum asperum Lepech. (up to $22 \%$ of protein) is promising [7]. The plantain family here is mainly presented by Platago saxatilis Bieb. (18,6\%) and P. caucasica Papava; the aster family - by Artemisia splendens Wild. (is eaten by sheep and goats), Scorsonera filifolia Boiss., Taraxacum crepidiforme $D C$.

Among the indifferent wild grasses forage there are species of the genus Alchemilla L. (13\%*), Potentilla L., Galium verum $L$. (about $8 \%)^{*}$, and G. rutenicum Willd., species Veronica L., Scabiosa caucasica Bieb., S. ochroleuca L., S. bipinata C. Koch., Campanula bibersteiniana Schult., Asyneuma campanuloides (M. Bieb. ex Sims) Bornm. (up to $10 \%$ ), Achillea millefolium L. (up to $10 \%)^{*}$, A. nobilis L., A. setacea Walst et Kit., Aster alpinum L., Inula grandiflora Willd. (about 11\%)*, Betonica grandiflora Stev. ex Wild. $=(B$. macrantha C. Koch). $(10 \%)^{*}$, etc.

The species of the family Liliaceae, Orchidaceae, Brassicaceae are almost not eaten (except only Crambe cordifolia Stev. containing 20,9\% of protein), as well as 
Ranunculaceae Juss., Papaveriaceae Juss., Violaceae Batsch, Saxifragaceae Juss. [7].

Many of these species are promising for the cultivation in the Caucasus, in the middle and northern parts of Russia, where they give high yields of green mass. The variegated brome, the hogweed of Sosnowski (15\% of protein), the persicaria of Panyutin (15-26\% of protein), the eastern galega, the sainfoin, etc. are especially important [7].

However, on the pastures there are a lot of harmful and poisonous plants that cause great harm to livestock. They form ballast, as they are not eaten either because of the unpleasant smell or taste, strong downiness, or because of thorns and coarse leaves. Among them there are some dangerous plants, for example, Equisetum arvense L., E. palustre L., Rhododendron luteum Sweet, Veratrum lobellanium Bernh. (especially for young animals); Colchicum speciosum Stev., C. laetum Stev. contain extremely poisonous alkaloids: colchicine, colchicerine, speciosin; Convallaria transcaucasica Utkin, Aristolochia clematitis L. is poisonous and make the milk poisonous as well; Polygonum persicaria L., Chenopodium vulgaria L., Stellaria graminea L., Herniaria caucasica, Saponaria officinalis L. - contains saponin saporubin $\mathrm{C}_{1} \mathrm{H}_{28} \mathrm{O}_{10}$, saporubin acid and glucoside; Caltha polypetala L., Helleborus caucasicus A. Br., all the species of the genus Delphinium L., especially, Aconitum L., the majority of species Ranunculus L., Anemone L., Pulsatilla Mill. containing the most dangerous heart poison (anemonol), Adonis L., especially A. vernalis L., species Papaver $L$., Fumaria L., Chelidonium majus L., Erysimum aureum Bieb, Sedum acre L., some of Galega orientalis Lam. and G. officinalis L., Coronilla varia L. - poisonous before flourishing mainly for sheep. The species of the genera Euphorbia L., Mercurialis L., Conium maculatum L. contain coniin, conidrin, $\left(\mathrm{C}_{8} \mathrm{H}_{17} \mathrm{O}\right)$, etc.; their poisonous qualities do not disappear after ensilaging or haymaking. Aethusa sinapium $L$. contains alkaloid cyanine, as well as some of the species Helyotropium L., Symphytum officinale L., Macrotomia echinoides (L.) Boiss. - contains alkaloid macrotomin $\mathrm{C}_{12} \mathrm{H}_{27} \mathrm{O}_{5}$, sometimes it can be found in Echium vulgare L., Cynoglossum officinale L., Verbena officinalis, Sideritis montana L., Galeopsis bifida Boenn., Stachys atherocalys C.Koch, S. pubescens Ten., Hyoscyamus niger L., Datura stramonium L., Digitalis grandiflora Mill., species of the genus Senecio L., in less quantities in Eupatorium cannabinum L.

Other plants cause mechanical damage, spoil the milk, meat, wool: the species of the genera Stipa L., Lappula Moench, Xanthium, Bidens, CirsiumMill., Carduus L., etc.

\section{A. Principles of Selection and Floral Composition of Grasses Recommended for Complementary Seeding in the Mountain Meadows of Chechnya and the North Caucasus}

As it was mentioned above, the floral composition of the majority of the pastures in the North Caucasus has to be improved. In some pastures Verartrum lobelium Bernh., Nardus stricta L., Festuca varia Haenke, Primula ruprechtii
Kusn., Molinia coerulea (L.) Moench, Anemone fasciculate L., Inula orientalis Lam., Trollius patulus Salisb, Betonica grandiflora Willd., Origanum vulgare L., Salvia verticillata L., Geranium gymnocaulon DC., the species of the genera Ranunculus L., Alchemilla L., Gentiana L., Aconitum L. are widely spread. One species Festuca varia Haenke (the most common grass of subalpine meadows) occupies up to $50 \%$ of the whole area of the alpine and subalpine pastures.

If the harmful and ballast species are removed from the grass stand, the pastures productivity doubles. If they are replaced with the most valuable species, then the actual yield of these meadows will increase threefold and fourfold.

Within this context the complementary seeding of herbs is of great importance. However, this activity has a positive effect only if the certain agrotechnical conditions are fullfilled and the plant species used for seeding are correctly selected. Complementary seeding without the prior thinning of the vegetation or with the usage of the "cultivated" or wild species that were neither local nor correctly selected had only negative results [8].

The basic principles of the herbs selection in addition to the well-known ones are as follows: the plants must have high fodder value, give a high yield of green mass, be resistant to trampling, grow well after grazing, have high competitiveness; these herbs ecology should conform to the specific climatic and edaphic conditions of pastures; the coenotic relations of the species should conform to the biotic factors of the meadow. In other words, the species selected for overseeding should be found in groups that are identical or allied to those that are typical of pastures to be improved [8].

The last three principles are not less important than the first four principles; they must be taken into account as well.

Only highly competitive species with a tendency to expansion can enter the cenosis, including the previously thinned one. Since the notion of competitiveness is relative, and it can only manifest itself in a specific situation, then the areas where the definite species can be "cultivated" are limited; moreover, these areas are not large.

When selecting species, it is necessary to take into account many factors: on the one hand, susceptibility of the plant to moisture, heat, on the other, the water and temperature regime of the pasture, susceptibility of plants to the chemical and physical properties of the soil - chemical richness and mechanical composition; and, besides, the coenotic abilities of species must be taken into account as without this knowledge it is impossible to select correct plants for seeding. For example, if Onobrychis biebersteinii Sirj. Together with Calamagrostis arundinacea (L.) Roth, Brachypodium pinnatum (L.) Beauv., Geranium platypetalum Fisch. et C.A. Mey., G. sanguineum L., Zerna variegate (Bieb.) Nevski grows in the mellowed meadows in Chechya, it can be recommended for the high mountain pastures with the predominance of Festuca supina Schur ot even F. varia Haenke. Both species are not typical of the groupings Festucetum supinae or 
Festucetum variae Haenke, or coenoses that are allied to them. But they can grow toghether with the variegated brome; so they can be seeded in the area of their expansion.

If these principles are strictly followed, the herbs seeding may become a real means of the real improvement of the natural forage lands of Chechnya and the entire North Caucasus. Unfortunately, it is still known little about the biology of wild plants, their confinement to various substrates (in view of chemical and physical properties) of the soil, especially about the obligatory degree of this confinement. There is little information about biotic relationships with allied and non-allied species, about the growth and development in a competitive environment, about the level of the specific ability during the different periods of life, about the seed productivity of wild species, etc.; it makes the work very difficult. However, these difficulties can be overcome, if, of course, the selection of species that are promising for seeding begins with studying these species in the natural environment.

Below there are the lists developed on the basis of the floral composition of the main types of meadows in Chechnya and adjacent territories, rates and methods of species expansion, their yield and fodder value, the dynamics of organic mat destruction in the mountainous areas, as well as the characteristics of the regeneration of the surface that is devoid of vegetation, for various reasons, etc. The lists are not complete. They need to be developed, improved and checked in the course of practice.

Each list contains species of different value. For a pasture type not more than 3-4 species should be recommended, the decision about the viability of the definite type is derived in every definite situation.

\section{B. Alpine Meadows (2800-3800 m)}

1) Plain areas and mild slopes (up to $10^{\circ}$ ) with small skeleton soils: Festuca supina Schur, F. ovina L., Colpodium variegatum (Boiss.) Tzvelev, Carex tristis M. Bieb., Hedysarum caucasicum M. Bieb., Plantago saxatilis M. Bieb., Poa alpina L., Koeleria caucasica (Domin) B. Fedtsch., Trifolium ambiguum Bieb.

2) Southern steep hills (up to $10^{\circ}$ ): Festuca aroides Lam., F. ovina L., Alopecurus sericeus Albov, Zerna variegate (Bieb.) Nevski, Anthyllis polyphylla = A. macrocephala Wend., Vicia alpestris Stev., Koeleria buschiana Gontsch., Hedysarum caucasicum Bieb, Arenaria lychnidea Bieb., Oxytropis kubanensis Leskov, Agrostis planifolia C. Koch.

3) Northern steep hills (up to $10^{\circ}$ ): Festuca aroides Lam., Carex tristis Bieb., Colpodium variegatum (Boiss.) Griseb., Koeleria caucasica (Domin)B. Fedtsch., Trifolium polyphyllum C.A. Mey., T. ambiguum Bieb., Carum caucasicum (Bieb.) Boiss., Poa alpina.

4) Waterlogged soil: Colpodium variegatum (Boiss.) Griseb., Hordeum violaceum Boiss. et Huet (up to 3000 m.), Taraxacum crepidiforme DC., Carum caucasicum (Bieb.) Boiss., Festuca rubraL., Trifolium spadiceum L. [3]

\section{Subalpine Meadows (1700-2500 m)}

1) Plain areas and mild slopes (up to $10^{\circ}$ ): Zerna variegate (Bieb.) Nevski, Festuca djimilensis Boiss. et Bal., F. pratensis Huds, Phleum montanum C. Koch., Brachypodium pinnatum (L.) Beauv., Trifolium ambiguum Bieb., T. fontanum Borb., T. pretense L., T. repens L., T. elisabethae Grossh., Koeleria caucasica (Domin) B. Fedtsch., Helictotrichon armeniacum (Schischk)Grossh., Deschampsia flexuosa (L.) Ness, Vicia caucasica Ekvtim, V. balansae Boiss.

2) Southern steep hills (up to $10^{\circ}$ ): Zerna variegata (Bieb.) Nevski, Festuca pratensis Huds, Helictotrichon armeniacum (Schischk) Grossh., H. pubescens (Huds.) Pilg., Phleum montanum C. Koch., Ph. phleoides (L.) Karst., Onobrychis biebersteinii Sirj., O. petraea (Bieb. ex Willd.) Fisch., Trifolium ambiguum Bieb., Medicago falcate L., M. glutinosa Bieb. (for the East Caucasus).

3) Northern steep hills (up to $10^{\circ}$ ): Zerna variegata (Bieb.) Nevski, Festuca ovina Schur, Colpodium variegatum (Boiss.) Griseb., Hedisarum caucasicum Bieb., Trifolium ambiguum M. Bieb., T. Polyphyllum C.A. Mey., Vicia caucasica Ekvtim, Phleum pratense L., Oxitropis kubanensis Leskov.

4) Waterlogged soil: Hordeum violaceum Boiss. et Huet, Festuca rubra, Phleum alpium, Ph. pratense L., Carum caucasicum (Bieb.) Boiss., Trifolium repens L., Agrostis planifolia K. Koch., Onobrychis biebersteinii Sirj. [3]

\section{Mid-Mountain Pastures (1000-1700 m)}

1) Plain areas and mild slopes (up to $10^{\circ}$ ): Zerna variegata Bieb., Z. riparia (Rehm.). Nevski, Z. biebersteinii (Roemer et Schultes) Nevski, Phleum phleoides (L.) H. Karst., Trifolium ambiguum M. Bieb., T. media L., T. repens L., Onobrychis biebersteinii Sirj., O. petraea (M. Bieb. ex Willd.) Fisch., Festuca pratensis Huds., F. djimilensis Boiss. \& Balansa, Medicago falcata L., Poa iberica Fisch. \& C.A. Mey., P. longifolia Trin., Anthyllis lachnophora Juz., Agrostis planifolia K. Koch.

2) Southern steep hills (up to $10^{\circ}$ ): Zerna variegata (Bieb.) Nevski, Festuca pratensis Huds, Helictotrichon armeniacum (Schischk) Grossh., H. pubescens (Huds.) Pilg., Phleum montanum C. Koch., Ph. phleoides (L.) Karst., Onobrychis biebersteinii Sirj., O. petraea (Bieb. ex Willd.) Fisch., Trifolium ambiguum Bieb., Medicago falcate L., M. glutinosa Bieb. (for the East Caucasus).

3) Northern steep hills (up to $10^{\circ}$ ): Zerna variegata (Bieb.) Nevski, Festuca pratensis Huds., Festuca djimilensis Boiss. et Bal., Poa longifolia Trin., Brachipodium pinnata (L.) Beauv, Helictotrichon adzharicum (Albov) Grossh., Phleum montanum C.Koch., Trifolium ambiguum M. Bieb., T. pratense L., T. fontanum Borb., Onobrychis biebersteinii K. Koch., Vicia caucasica Tkvtim.

4) Waterlogged soil: Hordeum violaceum Boiss. et Huet, Festuca rubra L., Phleum pratense pratense L., Carum caucasicum, Agrostis planifolia, Onobrychis biebersteinii, Trifolium repens L., T. pretense L., T. fontanum Borb., T. 
ambiguum M. Bieb., Zerna riparia (Rhem) Nevski, Poa pratensis.

5) Wood glades (high-grass): Dactyllis glomerata L., Festuca giganrtea L., F. pratensis Huds., Poa longifolia Trin, F. iberica Fisch., Briza media L., Trifolium pratense L., T. fontanum Bobrov, Vicia balansae Boiss., Onobrychis biebersteinii Sirj., O. cyri Grossh., Hordeum violacem Boiss. et Huet, Lathyrus pratensis L., Vicia dasicarpa Ten., Arrenantherum elatius (L.). J. et C. Presl, Brachypodium pinnatum (L.) Beav., Phleum phleoides (L.) Karst., Ph. pratense L. [3].

\section{E. Piedmont Pastures $(500-1000 \mathrm{~m})$}

1) Northern slopes: Festuca pratensis Huds., Brachipodium pinnata (L.) Beauv., Zerna riparia (Rehm.) Nevski, Z. inermis Leyss., Elytrigia trichophora (Link) Nevski, E. repens (L.) Desv. ex Nevski, Lolium perenne L., Poa longifolia Trin., P. iberica Fisch et C.A. Mey., Medicago falcate L., M. sativa, M. glutinosa, Trifolium ambiguum, T. pratense, Onobrychis cyri.

2) Southern slopes: Festuca sulcata (Hack.) Nym. p.p., Phleum phleoides (L.) H. Karst., Trifolium medium L., Onobrychis cyri Grossh., O. petraea (M. Bieb. ex Willd.), Medicago falcata L., Lotus corniculatus L., Zerna biebersteinii (Roemer et Schultes) Nevski, Z. inermis (Leyss.) Holub. [3].

\section{CONCLUSION}

The article describes the state of mountain meadows, their species composition. The fodder values of the great number of grasses, sedges, legumes and wild grasses recommended for improving natural meadows and pastures are defined. The types of the groups that have different economic value (well eaten, nutritious, of secondary importance, poisonous, weedy) are listed. The principles of the species selection for enrichment and qualitative improvement of mountain meadows are stated; they are developed taking into account the species feeding qualities, green mass yield, resistance to trampling, regenerative ability, high competitiveness and other bioecological features adequate to the conditions of the improved coenoses. The large set of species that are promising for the improvement of mountain pastures of different altitudes, orientations of slopes and various substrates is proposed. The research results are of practical importance and can be used in the practice of economic use of mountain meadows and pastures of the North Caucasus.

\section{References}

[1] M. A.-M. Astamirova, A.S. Abdurzakova, S.A. Israilova, R.S Magomadova, Kh.L. Khalidova, "Fodder Plants in the Flora of the Chechen Republic and Their Significance", In Proc. of the XVIII International Conference, 4-5 November 2016. Grozny, pp. 200-206. [Biological diversity of the Caucasus and Southern Russia, 2016]

[2] M.A. Taysumov, M.U. Umarov, M.A. Astamirova, A.S. Abdurzakova, Kh.L. Khalidova, "Species Potential of Useful Plants in the Mountain Regions of the Chechen Republic", Bulletin of KrasAU, no. 1, 2015, pp. 149-155.

[3] M.U. Umarov, M.A. Taysumov, "Phyto-Resources of the Subalpine and Alpine Belts of Mountain Regions", Porc. of the All-Russian ScientificPractical Conference, Grozny, pp. 325-338. [Topical Problems of Biology and Ecology, 2012]

[4] M.A. Taysumov, M.A.-M. Astamirova, S.A. Israilova, F.S Omarhadzhieva, "Questions of Protection and Prospects of Using the Genepool of the Flora of the Chechen Republic", In Proc. of the AllRussian Scientific and Practical Conference, 26-27 October 2011, Grozny, pp. 240-245. [Science. Education. Innovation, 2011]

[5] I.V. Larin, Sh.M. Agababyan, T.A. Rabotnov, A.F. Lyubskaya, V.K. Larina, M.A. Kasimenko, Fodder Plants of Hayfields and Pastures of the USSR, Moscow, -Leningrad, vol. 1. - p. 687; vol. 2.- p. 94; vol. 3. - p. 875 .

[6] A.A. Grossgeym, Vegetable Wealth of the Caucasus, Moscow, 1952, p. 631 .

[7] V.M. Bogdanov, Plants of Pastures of the Arid Zone of the North Caucasus and Their Fodder Value, Rostov-on-Don: North Caucasus, 1932, p. 43.

[8] S.S. Kharkevich, Useful Plants of the Natural Flora of the Caucasus and Their Introduction in Ukraine, Kiev, 1966, p. 301.

[9] V.G. Tanfiliev, Mountain Meadows of Karachay-Cherkessia and Their Improvement, Cherkessk, 1962, p. 40.

[10] Vegetable Resources of the USSR: Flowering Plants, Their Chemical Composition, Use; Families of Magnoliaceae-Limoniaceae, vol. 1, A.A. Fedorov Ed. Leningrad: Science, 1985; vol. 2, P.D. Sokolov Ed., Leningrad: Science, 1986, p. 336; vol. 3, P.D. Sokolov Ed., Leningrad: Science, 1987, p. 326; vol. 4, P.D. Sokolov Ed., Leningrad: Science, 1988 , p. 357. 